\title{
Pemberdayaan Umat Melalaui Program Distribusi Zakat Produktif Pada Badan Amil Zakat Nasional (BAZNAS) Kabupaten Lumajang
}

\author{
Yusuf Wibisono \\ STIE Widya Gama Lumajang \\ yusufwibisono1965@gmail.com
}

\begin{abstract}
Abstrak
Penelitian ini bertujuan untuk meneliti tentang distribusi zakat yang dilakukan oleh Badan Amil Zakat Nasional (BAZNAS) dalam program bantuan zakat produktif untuk pemberdayaan umat, khususnya kaum dhuafa' di Kabupaten Lumajang. Penelitian ini merupakan penelitian diskriptif kualitatif. Penelitian ini akan memberi gambaran secara sistematis dan akurat tentang masalah, keadaan dan peristiwa yang berkaitan dengan distribusi zakat produktif yang dilakukan oleh Badan Amil Zakat Nasional (BAZNAS) sebagaimana adanya. Dari beberapa program distribusi zakat BAZNAS yang menjadi fokus penelitian adalah distribusi zakat produktif, baik dalam bentuan bantuan modal usaha produktif bergulir untuk perorangan maupun kelompok. Karena zakat dapat dimanfaatkan untuk usaha produktif dalam rangka membantu peningkatan kualitas hidup umat, khususnya kaum fakir-miskin. Selanjutnya, dari hasil penelitian ini dapat diketahui bahwa program distribusi zakat, infaq dan shadaqah (ZIS) yang dilakukan oleh BAZNAS Kabupaten Lumajang terbukti sangat bermanfaat dan memberi konstribusi sangat positif terhadap para pengusaha kecil dalam pengembangan usaha mereka. Bantuan modal bergulir yang diberikan secara kelompok lebih bisa berkembang dengan baik, dibanding yang diberikan secara perorangan.
\end{abstract}

Kata kunci: Pemberdayaan umat, Zakat Produktif, Badan Amil Zakat Nasional (BAZNAS)

\begin{abstract}
Abstrac
This study aims to examine the distribution of zakat carried out by the National Zakat Agency (BAZNAS) in productive zakat assistance programs for the empowerment of people, especially the poor in the Lumajang Regency. This research is a qualitative descriptive study. This research will give a systematic and accurate description of the problems, circumstances and events related to the distribution of productive zakat carried out by the National Zakat Agency (BAZNAS) as it is. Of the several BAZNAS zakat distribution programs that are the focus of the research are productive zakat distribution, both in the provision of revolving productive business capital assistance for individuals and groups. Because zakat can be used for productive efforts in order to help improve the quality of life of the people, especially the poor. Furthermore, from the results of this study, it can be seen that the zakat, infaq and shadaqah (ZIS) distribution program carried out by the BAZNAS in Lumajang Regency proved to be very useful and gave a very positive contribution to the small entrepreneurs in developing their businesses. Revolving capital assistance provided in groups can be better developed, compared to those given individually.
\end{abstract}

\section{Keywords: Empowerment of the ummah, Productive Zakat, National Zakat Amil Agency (BAZNAS)}

\section{PENDAHULUAN}

Dalam pandangan Islam, dengan harta benda yang dimiliki, manusia diwajibakan menunaiakan zakat dan dianjurkan berderma dalam berbagai bentuk kedermawanan sesuai dengan kemampuan masingmasing. Dalam ayat-ayat Al-Qur'an dan Al-Hadits banyak menyebut kata zakat, infaq maupun shadqah. Berdasarkan penelitian, Al-Qur'an menyebut kata zakat sebanyak 30 kali. Kata infaq dalam berbagai bentuk 70 kali. Kemudian menyebut kalimat "shadaqah" (bentuk tunggal) sebanyak 5 kali dan dalam bentuk jama' nya shadaqat) sebanyak 8 kali.

Untuk menunaikan infaq dan shadaqah (harta), aturannya cukup longgar, baik menyangkut jumlah harta yang dimiliki, sedikit atau banyak, menyangkut kadar prosentasenya yang dikeluarkan maupun waktu mengeluarkannya. Sedangkan menyangkut syari'at zakat, memiliki ketentuan yang terperinci, baik menyangkut jumlah harta, harus sudah mencapai nishab, sudah sampai waktunya (haul), maupun kadar prosentasenya yang harus dikeluarkan, misalnya 2,5\%,5\%, $10 \%$ dan lain sebagainya.

Potensi zakat di Indonesia sungguh sangat besar. Menurut beberapa pendapat, potemsi zakat Indonesia bisa mencapai kisaran antara 19 hingga 32 trilyun rupiah. Untuk mengelola zakat tersebut, melalui Undang-Undang Nomor 23 tahun 2011 dan Peraturan Pemerintah Nomor 14 tahun 2014, Pemerintah memberikan mandat kepada Badan Amil Zakat Nasional dan Lembaga Amil Zakat (LAZ). 
Di Lumajang keberadaan BAZNAS sudah ada. Selama ini kiprahnya sudah dapat berjalan dengan baik. BAZNAS Kabupaten Lumajang dalam satu tahun sudah dapat menghimpun dana zakat, infaq dan shadaqah sebanyak Rp. 4,5 Milyar lebih.

\section{Rumusan Masalah}

Penelitian tentang Pemberdayaan Umat Melalui Program Distribusi Zakat Produktif Pada BAZNAS Kabupaten Lumajang ini penting dilakukan untuk turut serta memberikan solusi dalam pengelolaan dana zakat dan pengembangannya dengan langkah-langkah yang positif dan inovatif, selama tidak menyimpang dari ketentuan syari'at Islam dan peraturan perundang-undangan yang berlaku. BAZNAS Kabupaten Lumajang dituntut mampu mengelola dana zakat dengan penuh amanah, professional, transparan dan akuntabel. Sehingga hasilnya, pengelolaan zakatk itu dapat member manfaat nyata bagi kepentingan umat.

Berdasarkan paparan tersebut, maka dapat dirumuskan beberapa permasalahan sebagai berikut :

a. Bagaimana program pengumpulan dan pendistribusian zakat, infaq dan shadaqah yang dilakukan oleh BAZNAS Kabupaten Lumajang ?

b. Bagaimana strategi BAZNAS Kabupaten Lumajang dalam mengembangkan program distribusi zakat yang konsumtif dan produktif?

\section{METODE PENELITIAN}

Penelitian ini merupakan penelitian deskriptif kualitatif, dimana peneliti bermaksud menganalisis data dengan cara mendeskripsikan atau mengambarkan data yang telah terkumpul sebagaimana adanya tanpa bermaksud membuat kesimpulan yang berlaku untuk umum atau generalisasi.

\section{Definisi Konseptual}

Syari'at zakat, organisasi pengelola zakat (OPZ), Muzakki dan Mustahiq merupakan bagian penting dalam proses pengelolaan zakat, infaq dan shadaqah.

\section{Syari'at Zakat}

Zakat adalah salah satu rukun dari lima rukun Islam dan merupakan kewajiban dari sekian kewajiban dalam Islam. Kewajiban menunaikan zakat merupakan suatu kewajiban yang demikian tegas dan mutlak. Keberadaan zakat dianggap ma'lum min ad-din bi adh-dhaurah atau sesuatu yang sudah umum diketahui umat dan merupakan bagian mutlak dari keislaman seseorang.

Dasar pokok untuk melaksanakan syari'at zakat adalah ayat-ayat Al-Qur'an dan Al-Hadits. Dan seiring dengan perkembangan, zakat kini telah diatur dengan hukum formal, yaitu berdasarkan Undang-Undang Nomor 23 tahun 2011 tentang pengelolaan zakat dan Peraturan Pemerintah Nomor 14 tahun 2014 tentang Pelaksanaan Undang-Undang Nomor 23 tahun 2011 tentang pengelolaan zakat.

\section{Organisasi Pengelola Zakat}

Melalui berbagai regulasi yang telah dibuat oleh Pemerintah, kini Organisasi Pengelola Zakat (OPZ) semakin jelas status, tugas dan fungsinya. Menurut ketentuan Undang-Undang Nomor 23 Tahun 2011 dan Peraturan Pemerintah Nomor 14 Tahun 2014, yang ditunjuk pemerintah sebagai organisasi pengelola zakat (OPZ) adalah BAZNAS, LAZ dan Pengelola Zakat Perseorangan atau Kumpulan Perseorangan dalam Masyarakat di komunitas atau wilayah yang belum terjangkau oleh BAZNAS dan LAZ.

\section{Muzakki Dan Mustahiq}

Yang dimaksud dengan muzakki sebagaimana diatur dalam Undang-Undang Nomor 23 tahun 2011 pasal 1 adalah seorang muslim atau badan usaha yang berkewajiban menunaikan zakat. Yang menyangkut orang, dalam ketentuan ini muzakki itu harus orang muslim, tidak boleh non-muslim berzakat, ditambah lagi orang yang merdeka.

Sedangkan mustahiq adalah orang yang berhak menerima zakat. Mereka itu terbagi dalam delapan golongan (asnaf) sebagaimana ketentuan dalam Al-Qur'an surat At-Taubah ayat 60

\section{Pemberdayaan Zakat}

Pemberdayaan zakat dilakukan dalam bentuk distribusi zakat produktif. Yang dimaksud zakat produktif adalah pengelolaan dan penyaluran dana zakat yang bersifat produktif, yang mempunyai efek jangka panjang bagi para penerima zakat. Penyaluran dana zakat produktif ini dilakukan dalam rangka mewujudkan salah satu tujuan disyariatkannya zakat, yaitu mengentaskan kemiskinan umat secara bertahap dan berkesinambungan.

\section{HASIL DAN PEMBAHASAN}

Secara structural organisasi BAZNAS Kabupaten Lumajang dipimpin oleh 5 orang pimpinan, terdiri dari Ketua dan 4 Wakil Ketua, sesuai ketentuan pasal 41 Peraturan Pemerintah Nomor 14 Tahun 2014. Sebagai Ketua BAZNAS Kabupaten Lumajang adalah Drs. Affandi Latief Asnawi, MH. Sedangkan Wakil Ketuanya masing-masing adalah Drs. Sumartono, M.Si, H. Karmat, Sarwadi, SH. MH. dan Drs. Fathur Rokhim, M.Si. (Almarhum)

Dalam organisasi BAZNAS Kabupaten Lumajang disamping terdapat lima unsur pimpinan, juga ada unsur pelaksana. Untuk pelaksana mempunyai tugas pokok yang telah ditentukan, berdasar pembagian 
kerja, meliputi : (1). Bidang pengumpulan (2). Biadang pendistribusian dan pendayagunaan (3). Bagian perencanaan, keuangan dan pelaporan (4). Bagian Administrasi, SDM dan Umum

Untuk menjalankan tugas pengelolaan zakat, BAZNAS Kabupaten Lumajang secara rutin menyelenggarakan Rapat Kerja (Raker) tahunan. Berdasarkan hasil Raker BAZNAS Kabupaten Lumajang tahun selama tiga tahun terakhir, untuk program pengumpulan zakat, infaq dan shdaqah (ZIS) masih meneruskan kebijakan periode sebelumnya, yaitu lebih fokus pada penghimpunan ZIS dari para PNS di Kabupaten Lumajang.

Pengumpulan ZIS yang lebih fokus pada para PNS ini tidak terlepas dari ketentuan Undang-Undang tentang Pengelolaan Zakat, meskipun Undang-Undang memberi keleluasaan untuk menghimpun ZIS dari masyarakat luas. Sambil terus berjalan, BAZNAS Kabupaten Lumajang mengelola ZIS para PNS terlebih dahulu. Jika dihitung potensi ZIS dari PNS bisa mencapai jumlah sekitar Rp. 10 Milyar.

Berdasarkan data PNS di Kabupaten Lumajang, jumlah PNS sekitar 11.000. PNS yang dari Pemkab. Lumajang sebanyak 10.000 lebih. Ditambah dengan PNS dari Dinas/Instansi vertical seperti Kemenag, Kantor Pertanahan, Pengadilan Agama dan Pengadilan Negeri, Kejaksaan, dan lain-lain. PNS golongan IV sekitar 3.000 orang lebih. PNS golongan III sekitar 4.000 orang lebih. PNS golongan II dan I sekitar 3.000 orang.

PNS yang bisa diharapkan untuk menunaikan zakat adalah PNS golongan IV dan III, jumlahnya 7.000 orang lebih. PNS yang lain bisa diharapkan infaq dan shadaqahnya. Jika PNS golongan IV dan III bersedia membayar zakat profesi 2,5\% dari gajinya kurang lebih Rp. 4.000.000,- akan bisa terkumpul dana zakat sebanyak Rp. 700.000.000,- setiap bulan. Berarti mencapai Rp. 8.400.000.000,- (Delapan milyar empat ratus juta rupiah). Jumlah ZIS sebesar Rp. 8.400.000.000,- itu masih bisa ditambah dengan dana infaq dan shadaqah para PNS golongan II dan I.

Jika dianalisa lebih lanjut, yang paling menentukan adalah para PNS dan masyarakat, terutama mereka yang mampu. Artinya, proses dan keberhasilan dalam pengelolaan zakat tergantung pada kesadaran dan kemauan mereka untuk berzakat. Dan harus diterima sebagai kenyataan bahwa kesadaran untuk menunaikan zakat belum seperti yang diharapkan.

Dari kenyataan ini dapat difahami, bahwa pelaksaan kewajiban berzakat bukan hanya berkaitan dengan ketentuan syar'i ansich, tapi juga berkaitan dengan nilai-nilai yang bersifat sosiologis. Secara sosiologis, pelaksanaan kewajiban zakat belum menjadi budaya masyarakat. Masyarakat lebih suka untuk menunaikan infaq dan shadaqah dengan nominal yang variatif. Tantangannya adalah disamping memelihara dan menjaga budaya infaq dan shadaqah juga menumbuhkan budaya berzakat.

Hasil pengumpulan ZIS yang dilakukan oleh BAZNAS Kabupaten Lumajang selama ini terus mengalami kenaikan secara signifikan. Data pengumpulan ZIS pada tahun 2014 hingga 2016 secara umum sebagai berikut :

1. Bidang Pengumpulan tahun 2014. Target perolehan zakat, infaq dan shadaqah (ZIS) diperkirakan sebesar Rp. 2,5 Milyar. Pada akhir tahun 2014, berhasil mengumpulkan dana ZIS sebesar Rp. 2.819.791.185,- (Target terpenuhi)

2. Bidang Pengumpulan tahun 2015. Target perolehan zakat, infaq dan shadaqah (ZIS) diperkirakan sebesar Rp. 4 Milyar. Pada akhir tahun 2015, berhasil mengumpulkan dana ZIS sebesar Rp. 4.066.886.294,- (Target terpenuhi)

3. Bidang Pengumpulan tahun 2016. Target perolehan zakat, infaq dan shadaqah (ZIS) diperkirakan sebesar Rp. 4,5 Milyar. Pada akhir tahun 2016, berhasil mengumpulkan dana ZIS sebesar Rp. 4.715.196.457- (Target terpenuhi)

Hal itu dilakukan dengan beberapa langkah sebagai berikut :

a. Melakukan pendataan terhadap potensi calon muzakki baru, dengan target dapat menjaring dan menambah muzakki-muzakki baru.

b. Kemudian melaksanakan silaturahmi dan marketing zakat di lingkungan PNS antara lain silaturrahmi ke SDN, Guru SMPN, SMAN/SMKN, Anggota TNI, POLRI, dan Instansi Vertikal lain. Melakukan koordinasi dengan institusi potensial ke BUMN/BUMD seperti Bank, PG Jatiroto, PLN, Telkom dan sebagainya

c. Menganjurkan para PNS Guru dilingkungan Diknas untuk meningkatkan nominal ZIS-nya dari Rp. 50.000,- menjadi Rp. 75.000,- setiap bulan

d. Melakukan rekrutmen Tenaga Marketing Zakat untuk menambah jumlah muzakki baru yang mau membayar ZIS melalui BAZNAS.

e. Mengembangkan upaya pengumpulan Zakat Tijaroh (perdagangan) dan zakat Zuru' (hasil pertanian) yang selama ini belum tergarap.

f. Mengembangkan UPZ baru, yaitu UPZ masjid dan UPZ Sekolah

g. Penting juga dilakukan untuk meminta dukungan Pemerintah Daerah dalam rangka menggalang dana zakat dengan menerbitkan Surat Keputusan atau Surat Edaran Himbauan menyalurkan ZIS melalui BAZ Kabupaten Lumajang

4. Bidang Pendistribusian tahun 2014 
Program Tasharruf / Distribusi dana ZIS sebesar Rp. 2,701 Milyar. Distribusi zakat mencakup 8 Ashnaf yang terbagi dalam 5 bidang sasaran :

a. Program Lumajang Sejahtera dengan alokasi ZIS sebesar Rp. 1.251.202.000,- Dengan sasaran mustahiqnya santunan Ramadhan untuk 7.200 Fakir Miskin, Bantuan Sembako dan Bantuan Untuk Bencana Alam.

b. Program Lumajang Taqwa (Keagamaan) dengan alokasi dana sebesar Rp. 266.810.000,- Program ini diarahkan untuk Bantuan Lembaga Keagamaan, untuk : kegiatan, pembangunan, pengadaan sarana prasarana dan insentif Guru Ngaji, Dakwah dan Dai daerah terpencil.

c. Program Lumajang Sehat (KESEHATAN) dengan alokasi dana sebesar Rp.158.722.800,- Program ini diarahkan untuk membantu sejumlah kegiatan dibidang kesehatan, seperti program pengobatan Massal Gratis, Khitanan Massal, Bantuan Biaya Rawat Inap dan Bantuan Biaya Rawat Jalan

d. Program Lumajang Makmur (Ekonomi Produktif) dengan alokasi dana sebesar Rp. 243.200.000,Program ini diarahkan untuk Bantuan Modal Kerja Bergulir baik kelompok maupun perorangan dan Pelatihan Ketrampilan Kerja

e. Program Lumajang Cerdas (Pendidikan) dengan alokasi dana sebesar Rp. 415.905.000,- Program ini diarahkan untuk Bantuan beasiswa dalam bentuk uang untuk SMA/PT dan bantuan dalam bentuk Barang untuk siswa SD/MI dan SMP / MTs.

f. Disamping itu juga ada program distribusi kerjasama dengan UPZ-UPZ, yang dialokasikan dana sebesar Rp. 365.364.678,--

5. Bidang Pendistribusian tahun 2015

Kegiatan Tasharruf / Distribusi dana ZIS sebesar Rp. 3,299 Milyar. Distribusi zakat mencakup 8 Ashnaf yang terbagi dalam 5 bidang sasaran :

a. Program Lumajang Sejahtera dengan alokasi ZIS sebesar Rp. 1.165.521.100,- Dengan sasaran mustahiqnya santunan Ramadhan untuk Fakir Miskin, Bantuan Sembako dan Bantuan Untuk Bencana Alam.

b. Program Lumajang Taqwa (Keagamaan) dengan alokasi dana sebesar Rp. 690.439.143,- Program ini diarahkan untuk Bantuan Lembaga Keagamaan, untuk : kegiatan, pembangunan, pengadaan sarana prasarana dan insentif Guru Ngaji, Dakwah dan Dai daerah terpencil.

c. Program Lumajang Sehat (KESEHATAN) dengan alokasi dana sebesar Rp.272.008.900,-- Program ini diarahkan untuk membantu sejumlah kegiatan dibidang kesehatan, seperti program pengobatan Massal Gratis, Khitanan Massal, Bantuan Biaya Rawat Inap dan Bantuan Biaya Rawat Jalan

d. Program Lumajang Makmur (Ekonomi Produktif) dengan alokasi dana sebesar Rp. 263.943.500,Program ini diarahkan untuk Bantuan Modal Kerja Bergulir baik kelompok maupun perorangan dan Pelatihan Ketrampilan Kerja.

e. Program Lumajang Cerdas (Pendidikan) dengan alokasi dana sebesar Rp. 907.653.842- Program ini diarahkan untuk Bantuan beasiswa dalam bentuk uang untuk SMA/PT dan bantuan dalam bentuk Barang untuk siswa SD/MI dan SMP / MTs.

6. Bidang Pendistribusian tahun 2016

Tasharruf / Distribusi dana ZIS sebesar Rp.4.405 Milyar. Distribusi zakat mencakup 8 Ashnaf yang terbagi dalam 5 bidang sasaran :

a. Program Lumajang Sejahtera dengan alokasi ZIS sebesar Rp. 1.406.630.000,- Dengan sasaran mustahiqnya santunan Ramadhan untuk Fakir Miskin, Bantuan Sembako dan Bantuan Untuk Bencana Alam.

b. Program Lumajang Taqwa (Keagamaan) dengan alokasi dana sebesar Rp. 948.076.075,- Program ini diarahkan untuk Bantuan Lembaga Keagamaan, untuk : kegiatan, pembangunan, pengadaan sarana prasarana dan insentif Guru Ngaji, Dakwah dan Dai daerah terpencil.

c. Program Lumajang Sehat (KESEHATAN) dengan alokasi dana sebesar Rp.264.213.300,- Program ini diarahkan untuk membantu sejumlah kegiatan dibidang kesehatan, seperti program pengobatan Massal Gratis, Khitanan Massal, Bantuan Biaya Rawat Inap dan Bantuan Biaya Rawat Jalan

d. Program Lumajang Makmur (Ekonomi Produktif) dengan alokasi dana sebesar Rp. 196.000.000,Program ini diarahkan untuk Bantuan Modal Kerja Bergulir baik kelompok maupun perorangan dan Pelatihan Ketrampilan Kerja

e. Program Lumajang Cerdas (Pendidikan) dengan alokasi dana sebesar Rp. 1.026.155.441,-- Program ini diarahkan untuk Bantuan beasiswa dalam bentuk uang untuk SMA/PT dan bantuan dalam bentuk Barang untuk siswa SD/MI dan SMP / MTs.

f. Mulai tahun 2016 ini distribusi zakat dialokasi secara terbuka untu hak amil, sesuai ketentuan Undang-Undang dan aturan-aturan pelaksanaan lainnya.

Dari data laporan BAZNAS Kabupaten Lumajang tahun 2014 sampai 2016 diatas terlihat program distribusi untuk bantuan modal usaha ekonomi produktif selalu dianggarkan, meskipun nilai nominalnya mengalami fluktuasi naik turun. Pada tahun 2016 mengalami penurunan dibanding dua tahun sebelumnya, dengan alokasi dana sebesar Rp. 196.000.000,- 
Program pengelolaan dana zakat, infaq dan shadaqah di BAZNAS Kabupaten Lumajang, dana ZIS yang sudah terkumpul tidak dengan sendirinya dibagi-bagi habis secara konsumtif kepada para mustahiq, tetapi dikembangkan dengan cara-cara baru yang kreatif, disamping dengan cara konsumtif juga dengan cara produktif, seperti dimuat pada majalah BAZNAS 50 bulan Juli-Agustus 2017 :

1. Distribusi ZIS secara konsumtif

a. Konsumtif tradisional, zakat diberikan secara langsung kepada mustahiq untuk kebutuhan konsumtif sehari-hari. Pada momen bulan Ramadhan yang lalu BAZNAS Kabupaten Lumajang membagikan dana ZIS sebesar Rp. 1 Milyar kepada keluarga miskin yang tersebar se Kabupaten Lumajang.

b. Konsumtif kreatif, zakat disamping diberikan dalam bentuk uang juga bisa diwujudkan dalam bentuk barang atau alat-alat. Misalnya, pada momen upacara Hardiknas tanggal 2 Mei 2017, BAZNAS menyerahkan bantuan beasiswa kepada anak-anak sekolah dan mahasiswa sebesar Rp.300.000.000,-

2. Distribusi ZIS secara produktif

a. Produktif konvensional, zakat diberikan dalam bentuk barang produktif yang memungkinkan bagi penerima untuk mengembangkan usahanya. Program ini kurang berkembang di BAZNAS Kabupaten Lumajang.

b. Produktif Kreatif, zakat diberikan dalam bentuk bantuan modal usaha bergulir bagi para pengusaha kecil. Diberitakan di majalah, BAZNAS Lumajang memberikan pembinaan administrasi dan manajemen kepada 15 pengusaha mikro yang selama ini menjadi mitra binaan BAZNAS, yang terdiri dari 5 kelompok usaha dan 10 pengusaha mikro perorangan. Ketua BAZNAS Kabupaten Lumajang mengatakan, jika para pengusaha itu amanah dalam menjalakan usahanya bekerjasama dengan BAZNAS, maka bukan tidak mungkin BAZNAS bisa menambah jumlah nominal bantuan modal usaha tersebut.

Beberapa hal terkait dengan jumlah bantuan modal bergulir yang bervariasi yang dilakukan oleh BAZNAS Kabupaten Lumajang, baik yang diberikan kepada perorangan maupun kepada kelompok sebagai berikut :

1. Jumlah bantuan modal bergulir yang diberikan kepada Kelompok Usaha (KU) tahun 2014 sebanyak 10 KU. Tahun 2015 sebanyak 9 KU dan tahun 2016 sebanyak 3 KU. Beberapa KU telah mendapatkan beberapa kali bantuan, yang menunjukkan berkembangannya baik dan lancar. Nilai bantuan bervariasi dari yang terkecil sebesar Rp. 3.000.000,- sampai yang tertinggi Rp. 30.000.000,-

2. Jumlah bantuan modal bergulir yang diberikan kepada perorangan setiap tahun hampir sama, pada tahun 2014 sebanyak 19 orang. Tahun 2015 sebanyak 20 orang. Tahun 2016 sebanyak 18 orang. Nilai bantuan juga bervariasi dari yang terkecil sebesar Rp. 500.000,- sampai yang tertinggi Rp. 10.000.000,-

3. Ketika wawancara dengan pimpinan BAZNAS Kabupaten Lumajang, bantuan yang diberikan memang bervariasi, baik yang diberikan kepada perorangan maupun kepada KU. Hal itu disesuaikan dengan potensi usaha masing-masing. Untuk KU juga ditentukan oleh jumlah anggota KU.

4. Sesuai dengan namanya, bantuan itu diberikan dalam bentuk (semacam) pinjaman yang dikembalikan kepada BAZNAS secara angsuran. Bantuan modal bergulir itu diberikan tanda bunga (jasa). Hanya yang bersangkutan dianjurkan untuk berinfaq sesuai keikhlasan. Dengan cara seperti itu dimaksudkan sebagai upaya mendidik para mustahiq untuk merubah menjadi muzakki atau munfiq.

5. Bantuan modal bergulir yang diberikan kepada KU rata-rata dapat berjalan dengan baik. Sedangkan bantuan modal bergulir yang diberikan kepada perorangan kurang atau tidak berjalan lancar.

Jika dianalisa lebih dalam, ada beberapa hal yang perlu dicermati lebih lanjut dari program distribusi zakat, infaq dan shadaqah yang telah dilakukan oleh BAZNAS.

1. Program Distribusi zakat yang dilakukan oleh BAZNAS Kabupaten Lumajang sebenarnya dimungkinkan untuk diambil dari dana zakat. Tetapi program itu harus sesuai dengan ketentuan Undang-Undang dan pedoman pendistribusian zakat, terutama untuk program pemberdayaan dan pendayagunaan zakat. Dalam hal ini Undang-Undang telah menentukan bahwa program pendistribusian dana zakat, infaq dan shadaqah yang dilakukan oleh BAZNAS hendaknhya mengikuti aturan sebagai berikut :

a. Zakat wajib didistribusikan kepada mustahiq sesuai dengan syari'at Islam, yaitu untuk delapan asnaf

b. Zakat hendaknya didistribusikan dengan skala prioritas, dengan memperhatikan prinsip pemerataan, keadilan, dan kewilayahan

c. Zakat dapat didayagunakan untuk usaha produktif dalam rangka penanganan fakir miskin dan peningkatan kualitas umat. Hal ini dapat dilakukan jika kebutuhan dasar mustahiq telah terpenuhi

d. Pendistribusian dan pendayagunaan infaq, shadaqah dan dana sosial keagamaan lainnya dilakukan sesuai dengan syari'at Islam dan dilakukan sesuai dengan peruntukan yang diikrarkan oleh pemberi. Ketentuan dalam Undang-Undang ini dirasakan oleh pimpinan BAZNAS Kabupaten Lumajang tidak semudah yang diprogramkan, sehingga Pimpinan BAZNAS Kabupaten Lumajang mengambil langkah aman, dengan cara membuat program bantuan modal usaha bergulir, dengan mengambil sumber dananya dari dana infaq dan shadaqah, bukan dari dana zakat. Karena dana infaq dan shadaqah pemanfaatannya lebih leluasa sepanjang pemanfaatannya itu tidak bertentangan dengan syari'at Islam 
dan ketentuan huikum zakat. Menurut penjelasan Ketua BAZNAS Kabupaten Lumajang, program bantuan modal usaha bergulir itu pernah dipersoalkan oleh sebagaian ualama' di Lumajang. Zakat kok dipinjam-pinjamkan. Seharusnya langsung dibagikan. Oleh karena itu, strategi yang dilakukan, dengan memanfaatkan dana infaq dan shadaqah. Bukan dana zakat.

2. Strategi selanjutnya, dalam memberikan bantuan pinjaman modal usaha bergulir menggunakan akad Qodrul Hasan, yaitu pengembalian pinjaman tanpa adanya uang tambahan atau yang lebih dikenal dengan istilah bunga atau jasa. Ketentuan itu dapat difahami bahwa Badan Amil Zakat Nasional (BAZNAS) Kabupaten Lumajang dalam memberikan bantuan modal usaha pada para mustahik betulbetul bermanfaat untuk menambah modal tanpa harus memberi beban uang tambahan dalam bentuk bunga atau jasa. Hanya saja BAZNAS menentukan, bahwa mustahiq yang diberi bantuan tersebut haruslah benar-benar orang yang amanah, meiliki keterampilan dalam mengembangkan usaha, dan bisa mengembangkan modal yang telah diberikan oleh BAZNAS Kabupaten Lumajang, sehingga akan nyata hasilnya.

3. Disamping menggunakan skema akad Qardul Hasan dalam distribusi zakat produktif, sebenarnya bisa juga penyaluran dana zakat produktif itu memanfaatkan skema akad mudhorobah. Dalam hal ini BAZNAS dapat bertindak sebagai investor atau modhorib yang menginvestasikan dana hasil pengumpulan dana ZIS kepada mustahik, sebagai peminjam dana yang ditutut tingkat pengembalian tertentu, dengan angsuran pinjaman ditambah bagi hasil keuntungan. Antara skema akad mudhorobah dan akad Qordul Hasan hampr sama. Namun yang membedakan adalah apibala usaha tersebut menghasilkan keuntungan (ada labanya) maka mustahik mengambil sejumlah persen laba untuk diberikan kepada BAZNAS beikut modalnya. BAZ menerima modal kembali, ditambah dengan sekian presen dari keuntungan usaha. Tapi skema kedua ini tidak dilakukan oleh BSAZNAS Kabuoaten Lumjajang.

4. Dari pengalaman yang sudah berjalan, tidak semua yang mendapat bantuan modal usaha bergulir itu sukses. Tentu ada saja yang tidak sukses. Modalnya habis. Akibatnya tidak bisa mengembalikan kepada BAZNAS. Menurut penjelasan Wakil Ketua BAZNAS yang membidangi pendistribusian, Sarwadi, SH. MH. Dan Atok Hasan Sanusi : Untuk kelompok rata-rata bisa berjalan lancar. Untuk perorangan ada sebagain yang memang tidak mengembalikan bantuan modal tersebut. Dalam kasus seperti ini, yaitu jika ada orang-orang yang tidak mengembalikan pinjaman dana bergulir ini bahkan tidak dicicil oleh mustahik, maka pengurus Badan Amil Zakat Nasional (BAZNAS) Kabupaten Lumajang akan menggunakan beberapa cara, antara lain dengan memberikan suatu teguran kepada yang bersangkutan sebagai upaya penagihan, namun jika tetap tidak berhasil, maka dana tersebut dinyatakan sebagai sumbangan. Berarti orang tersebut sudah tidak amanah, maka konsekuensinya, dia tidak akan mendapatkan bantuan modal usaha lagi.

5. Alokasi dana untuk program bantuan modal usaha bergulir di BAZNAS Kabupaten Lumajang relatif kecil. Bahkan untuk tahun 2016 mengalami sedikit penurunan. Pada tahun 2014, Program Lumajang Makmur (Ekonomi Produktif) dialokasikan dana sebesar Rp. 243.200.000,- Untuk tahun 2015 dialokasikan dana sebesar Rp. 263.943.500,- Dan untuk tahun 2016 dialokasikan dana sebesar Rp. 196.000.000,- Padahal dilihat dari perolehan pengumpulan ZIS terus mengalami kenaikan. Seharusnya alokasi dana untuk program bantuan modal usaha bergulir di BAZNAS Kabupaten Lumajang turut mengalami kenaikan.

\section{KESIMPULAN DAN SARAN \\ Kesimpulan}

Berdasarkan hasil penelitian Pemberdayaan Umat Melalui Program Distribusi Zakat Produktif Pada

BAZNAS Kabupaten Lumajang dapat dibuat beberapa kesimpulan sebagai berikut :

1. Program pengelolaan zakat selama tiga tahun terakhir dapat berkembang dengan baik. Dari segi pengumpulan dana ZIS, BAZNAS Kabupaten Lumajang dapat memenuhi target yang telah diputuskan melalui Rapat Kerja BAZNAS tahun 2014, 2015, dan 2016. Dana ZIS yang telah dikumpulakan mencapai Rp. 4.5 Milyar lebih.

2. Dari dana ZIS yang telah dikumpulkan itu kemudian didistribusikan kepada mustahiq baik secara konsumtif maupun produktif. Untuk distribusi zakat produktif yang dilakukan oleh BAZNAS Kabupaten Lumajang sudah berjalan dengan baik, terutama yang dilakukan melalui bantuan modal usaha bergulir untuk Kelompok Usaha.

3. Untuk memudahkan pengelolaan dan pertanggungjawabannya, Pimpinan BAZNAS mengabil dana infaq dan shadaqah sebagai sumber program pemberdayaan ZIS, bukan dari sumber dana zakat.

4. Program pemberdayaan zakat dilakukan dengan akad Qardhul Hasan, yang memberi bantuan modal usaha bergulir tanpa ada tambahan bunga atau jasa.

\section{Saran-saran}

Beberapa saran perlu disampaikan dalam rangka peningkatan pengelolaan ZIS pada BAZNAS Kabupaten Lumajang: 
1. Pimpinan BAZNAS Kabupaten Lumajang bersama jajaran UPZ-nya harus bekerja lebih optimal, agar pengumpulan ZIS-nya lebih meningkat lagi, sesuai dengan potensi ZIS yang dimiliki oleh Kabupaten Lumajang.

2. Program pemberdayaan zakat hendaknya lebih dikembangkan lagi, bukan hanya bersumber dari dana infaq dan shadaqah, tapi juga dari dana zakat.

3. Program pemberdayaan zakat hendaknya lebih difokuskan pada bantuan modal usaha bergulir melalui kelompok usaha, karena lebih bisa amanah dan lebih bermanfaat.

\section{DAFTAR PUSTAKA}

Abu Izzudin, Solikhin, 2014, Happy Ending Full Barokah, Pro-U Media, Yogyakarta Aflah, K. N. dan M. N. Tajang (Ed), 2006, Zakat Dan Peran Negara, FOZ, Jakarta Ali Hasan, M. 2003, Masail Fiqhiyah, PT Raja Grafindo Persada, Jakarta

Al-Zuhayly, Wahbah, 2008, Zakat Kajian Berbagai Madzhab. PT. Remaja Rosdakarya, Bandung Buchory, Abdusshomad, 2008, Zakat Sebuah Potensi Yang Terlupakan, BAZ Jawa Timur, Surabaya Departemen Agama RI, 2003, Pedoman Pengelolaan Zakat, Jakarta Departemen Agama RI, 2007, Standarisasi Manajemen Zakat, Jakarta. Kementerian Agama RI, 2010, Panduan Organisasi Pengelola Zakat, Jakarta. Kementerian Agama RI, 2010, Panduan Pengembangan Usaha Bagi Mustahiq, Jakarta. Hafidhuddin, Didin, 2009, Agar harta Berkah Dan Bertambah, Gema Insani, Jakarta Huda, Nur Cholis, 2015, Islam Itu Mudah, Hikmah Press, Surabaya Hamzah, Ali, 2014, Pendidikan Agama Islam Untuk Perguruan Tinggi, Alfabeta, Bandung. Khalid, Amru, 2009, Ibadah Sepenuh Hati, Aqwam, Kartasura. Qardhawi, Yusuf, 2004, Hukum Zakat, Pustaka Lentera Antarnusa, Jakarta Rasjid, Sulaiman, 2007, Fiqh Islam, Sinar Baru Algensindo, Bandung Ruslan, Rosady, 2003, Metode Penelitian Public Relations dan Komunikasi, PT. Raja GrafindoPersada, Jakarta

Sabiq, Sayyid , 1978, Fikih Sunnah Jilid 3, Al-Ma'arif, Bandung

Shihab, M. Quraish, 1999, Fatwa-Fatwa Seputar Ibadah Mahdah,Mizan, Bandung

Sudirman dan R. N. Arifah (Ed), 2008, The Power Of Zakat, Study Perbandingan Pengelolaan Zakat Asia Tenggara, UIN Malang Press, Malang

Sugiyono, 2008, Metode Penelitian Kuantitatif Kualitatif dan R\&D, ALFABETA, Bandung

Thobroni, Muhammad, 2008, Mukjizat Sedekah, Pustaka Marwa, Yogyakarta

Wibisono, Yusuf, 2010, Berbagi Zakat Dengan Sentuhan Cinta, BAZ, Lumajang

Wibisono, Yusuf, 2012, Berbagi Jangan Tunda Zakat Anda, BAZ, Lumajang

Undang-Undang Republik Indonesia Nomor 23 Tahun 2011 Tentang Pengelolaan Zakat

Peraturan Pemerintah Republik Indonesia Nomor 14 Tahun 2014 Tentang Pelaksanaan Undang-Undang Republik Indonesia Nomor 23 Tahun 2011 Tentang Pengelolaan Zakat

Peraturan Bupati Lumajang Nomor 50 Tahun 2016 Tentang Pengelolaan Zakat, Infaq Dan Sedkah http://pusat.baznas.go.id/tugas-pokok-baznas (Diakses 25 September 2017) http://kablumajang.baznas.go.id/cgi-sys/suspendedpage.cgi (Diakses 25 September 2017)

http://asyirahaswajasumut.blogspot.co.id/2015/06/meluruskan-pemahaman-amil-zakat-di.html (Diakses 25 September 2017)

https://rachmatfatahillah.blogspot.co.id/2013/03/zakat-konsumtif-dan-zakat-produktif.html. $\quad$ (Diakses 29 September 2017) 